\title{
Finnish vocational education and training in comparison: Strengths and weaknesses
}

\author{
Maarit Virolainen* \\ University of Jyväskylä \\ Finnish Institute for Educational Research \\ P.O. Box 35, FI-40014 University of Jyväskylä, Finland \\ E-mail: maarit.ha.virolainen@jyu.fi

\section{Marja-Leena Stenström} \\ University of Jyväskylä \\ Finnish Institute for Educational Research \\ P.O. Box 35, FI-40014 University of Jyväskylä, Finland \\ E-mail: marja-leena.stenstrom@jyu.fi \\ * Corresponding author
}

\begin{abstract}
The study investigates how the Finnish model of providing initial vocational education and training (IVET) has succeeded in terms of enhancing educational progress and employability. A relatively high level of participation in IVET makes the Finnish model distinctive from those of three other Nordic countries: Denmark, Norway and Sweden. All four Nordic countries have wellorganised labour markets and universal types of welfare states. Priority is given to goals related to equal opportunities and social inclusion. At the same time, these countries have different models of IVET. While the study compares the Finnish model of organising IVET to those of other Nordic countries, it also examines the German and UK models, which represent differing societal approaches to IVET. The differences in the outcomes of the IVET systems are described and analysed through reviewing secondary data provided by Eurydice and Eurostat, along with country reports produced in a Nordic comparative project, Nord-VET.
\end{abstract}

Keywords: Comparative study, educational trends, initial vocational education and training, participation, access to higher education, level of employment

\section{Bibliographical notes:}

$\mathrm{PhD}$ Maarit Virolainen is a researcher at the Finnish Institute for Educational Research at the University of Jyväskylä, Finland. Her research interests focus on learning from work experience, cooperation and collaboration between the working world and educational institutions, educational careers and transitions from education to working life. 
$\mathrm{PhD}$ Marja-Leena Stenström is a professor at the Finnish Institute for Educational Research at the University of Jyväskylä, Finland. Her research interests cover educational careers, vocational education and occupational skills and the relationships and transitions between education and working life. 


\section{Introduction}

The low status of initial vocational education and training (IVET) ${ }^{1}$ offered as postcompulsory education has often been a concern for educational policymakers and education providers (Billett, 2014; Polesel, 2010; Young and Raffe, 1998). As an educational route, IVET has carried the stigma of leading to lower-paid employment and lower-status occupations compared to higher education programmes. Furthermore, it has been seen as the choice for those whose parents come from a lower educational background, while children of parents with higher education follow their parents' examples and graduate from higher education more often (Nori, 2010; Paterson and Iannelli, 2007). In most societies, social selection, which takes place through tracked upper secondary systems, creates IVET as a route for the less fortunate with respect to general education (Bourdieu and Passeron, 1977). In general, the low status of IVET has been related to issues of participation and high drop-out rates compared to general upper secondary and higher education. Still, the role of IVET is crucial for societies because of the need for an adequate supply of competent work-force labourers.

Against the odds, participation in IVET in Finland has been growing slightly since 2003. In 2003, 55.1\% of those who had completed compulsory education went directly to general upper secondary schools, while $37 \%$ went to IVET (Statistics Finland, 2008). In Finland, general upper secondary schools prepare students for tertiary education, but do not qualify them for the labour market, whereas IVET qualifies students for the labour market and also provides eligibility for tertiary education. By 2008, the share of those choosing IVET immediately after the completion of compulsory education had increased to $42 \%$, and it has remained at 41-42\% since then (Cedefop, 2011; Statistics Finland, 2012). At the same time, the share of those continuing in general upper secondary education has decreased to $50-51 \%$ (Statistics Finland, 2012). This increased level of participation in IVET makes the Finnish model distinctive and interesting with respect to the vocational education systems of the other Nordic countries as well as other European countries. Therefore, this paper aims to compare the Finnish model of IVET, and especially the outcomes of IVET with respect to completion of general upper secondary education and tertiary education, to other-in particular, Nordic, German and British - models of IVET.

The comparison of the four Nordic countries' (Finland, Denmark, Norway and Sweden) distribution of upper secondary students with respect to school types (general or vocational) in the years 2000, 2006 and 2009 against the same data from Germany and the United Kingdom is presented in Table 1. The figures in Table 1 have been taken from reports provided by the European Commission. The initial sources for these figures have been Eurostat and Labour Force Survey. Typically, this information has been extracted from the databases about a year before publishing and it refers to figures collected a few years earlier (EACEA P9, 2009; EACEA P9, 2012; Eurydice European Unit and Statistical Office Eurostat, 2002). These figures confirm the uneven expansion of VET.

The paper primarily addresses initial vocational education (IVET), organised as postcompulsory education for young entrants aged 15-16 years (ISCED 3 level), unless stated otherwise. 
Table 1: Distribution of upper secondary students (ISCED 3) by programme type (general or vocational)

\begin{tabular}{|c|c|c|c|c|c|c|}
\hline & $\begin{array}{l}\text { Finland } \\
\text { (FIN) }\end{array}$ & $\begin{array}{l}\text { Denmark } \\
\text { (DK) }\end{array}$ & \begin{tabular}{|l} 
Norway \\
$(\mathrm{NO})$
\end{tabular} & $\begin{array}{l}\text { Sweden } \\
\text { (S) }\end{array}$ & $\begin{array}{l}\text { Germany } \\
\text { (D) }\end{array}$ & \begin{tabular}{|l} 
United \\
Kingdom \\
$(\mathrm{UK})$
\end{tabular} \\
\hline $\begin{array}{l}\text { 1999/2000 } \\
\text { Vocational } \\
\text { General }\end{array}$ & $\begin{array}{l}55.3 \\
44.7\end{array}$ & $\begin{array}{l}54.7 \\
45.3\end{array}$ & \begin{tabular}{|l|}
57.3 \\
42.7
\end{tabular} & $\begin{array}{l}48.8 \\
51.2\end{array}$ & $\begin{array}{l}63.2 \\
36.8\end{array}$ & $\begin{array}{l}67.3 \\
32.7\end{array}$ \\
\hline $\begin{array}{l}2006 \\
\text { Vocational } \\
\text { Total } \\
\text { Males } \\
\text { Females } \\
\text { General } \\
\text { Total } \\
\text { Males } \\
\text { Females }\end{array}$ & $\begin{array}{l}65.4 \\
68.6 \\
62.5 \\
34.6 \\
31.4 \\
37.5\end{array}$ & $\begin{array}{l}47.8 \\
55.3 \\
40.7 \\
\\
52.3 \\
44.7 \\
59.3\end{array}$ & $\begin{array}{l}60.0 \\
66.1 \\
53.4 \\
40.0 \\
33.9 \\
46.6\end{array}$ & $\begin{array}{l}55.1 \\
58.8 \\
52.0 \\
44.9 \\
41.2 \\
48.0\end{array}$ & $\begin{array}{l}59.4 \\
64.9 \\
53.2 \\
\\
40.6 \\
35.1 \\
46.8\end{array}$ & $\begin{array}{l}41.7 \\
40.6 \\
42.8 \\
58.3 \\
59.4 \\
57.2\end{array}$ \\
\hline $\begin{array}{l}2009 \\
\text { Vocational } \\
\text { Total } \\
\text { Males } \\
\text { Females } \\
\text { General } \\
\text { Total } \\
\text { Males } \\
\text { Females }\end{array}$ & $\begin{array}{l}68.8 \\
72.2 \\
65.7 \\
31.2 \\
27.8 \\
34.3 \\
\end{array}$ & \begin{tabular}{|l}
47.3 \\
54.2 \\
40.6 \\
\\
52.7 \\
45.8 \\
59.4 \\
\end{tabular} & \begin{tabular}{|l}
54.1 \\
61.6 \\
45.7 \\
45.9 \\
38.4 \\
54.3 \\
\end{tabular} & $\begin{array}{l}56.4 \\
60.0 \\
53.2 \\
43.6 \\
40.0 \\
46.8 \\
\end{array}$ & \begin{tabular}{|l}
53.2 \\
60.5 \\
44.5 \\
46.8 \\
39.5 \\
55.5 \\
\end{tabular} & $\begin{array}{l}30.5 \\
30.7 \\
30.4 \\
\\
69.5 \\
69.3 \\
69.6\end{array}$ \\
\hline
\end{tabular}

Notes. Adopted from EACEA P9, 2009; EACEA P9, 2012; Eurydice European Unit and Statistical Office Eurostat, 2002. Years 1999/2000, 2006 and 2009.

In Finland, there were 55.5\% students participating in IVET in 2000, with this share increasing to $68.8 \%$ by 2009 . The numbers are different from those presented above in Table 1, because 'all standard education programmes' have been included in the table, as well as all adult education if its 'subject content is similar to standard education programmes' or has led to 'qualifications which are similar to corresponding standard programmes' (EACEA P9, 2009; EACEA P9, 2012; Eurydice European Unit and Statistical Office Eurostat, 2002). The information about lifetime participation requires a longitudinal perspective. In the Finnish case, other statistics show that when the prior education of those attending IVET immediately after compulsory education is considered, the participation rate looks somewhat different. Still, the share of those moving to IVET has been increasing. In 2012, around half of the students (48.6\%) who attended IVET entered their education directly after compulsory education (Statistics Finland, 2014a). Furthermore, additional data regarding the educational background of IVET entrants shows that there are many adults participating in IVET in Finland. For example, in 2004 , the majority of the $72 \%$ who started IVET had only completed compulsory education and belonged to the group of youth that the education is primarily addressing (Stenström and Valkonen, 20125). The rest had completed the matriculation examination of general upper secondary education (14\%), other IVET qualifications (14\%) or combinations of these or other qualifications 
(Stenström and Valkonen, 2012). In other words, this route also serves as a route for adult education in Finland. Despite their differing approaches, the statistics presented in Table 1 confirm that participation in VET and delivery of VET, which is considered - at least contentwise - equal to IVET, has increased in Finland and Sweden and decreased in the other countries addressed in this comparison.

In order to understand the reasons behind the increased participation in IVET in Finland, we compare the Finnish model of IVET to the three other Nordic models of IVET (Denmark, Norway and Sweden) and make also some references to Germany and the UK. We explore whether there are systemic strengths in the Finnish IVET by investigating how the high participation rate in IVET is congruent with completion of both general upper secondary and vocational education (upper secondary education, ISCED 3), educational progress to tertiary education and employability. We also try to find reasons for the increased participation rates in Finland by comparing IVET models. We explore what kind of outcomes, in terms of progress to higher education and employability, are related to increased participation in IVET in Finland. Furthermore, we compare the Finnish model to other countries' IVET models to determine whether there are known characteristics of IVET that differentiate the Finnish IVET system from other models. We also discuss whether there are issues to consider before making hasty conclusions about the status of Finnish IVET.

In the following sections, we characterise the common Nordic context through terms of the universalistic transition regime. We also describe how the universalistic regime differs from the employment-centered regime and the liberal regime typical to Germany and the UK. Thereafter, we describe how the Finnish model of IVET differs from the models in other countries included in the comparison ${ }^{2}$. Next, we present our research questions and data and then discuss the limitations of addressing our study questions with the secondary data we have used in this study. We then present our results, and finally conclude with a discussion of our results concerning the participation patterns in Finnish IVET.

\section{The Nordic context of IVET and its diversity with respect to Germany and the UK}

Walther characterized the Nordic welfare states as a universalistic regime regarding their participation in education (Walther, 2009). The regime model is based on a generalization of features into ideal types typical of several national transition systems. It allows the generalization of groups of countries according to overall rationales that direct life-courses. The existing national models may, however, consist of features that are typical to other regimes. The origin of regimes is dependent on nation states' construction of welfare systems, institutional contracts and legislation on the basis of earlier structures and their historical processes. They reflect stability of social institutions from decade to decade (Walther, 2009).

In the universalistic regime, which dominates as the transition regime of Nordic countries, education and training pathways are planned to be inclusive and flexible to individual choices (Walther, 2009). The universalistic regime differs from other regimes, such as the employment-centred regime, liberal transition

2 The country-reports and analysis produced in the project 'The future of Vocational education - learning from the Nordic countries' (financed by NordForsk) have provided invaluable background information for the comparisons and analysis of this investigation (see Jørgensen, 2013). 
regime and sub-protective transition regime, in several respects. First, social security is organized by the state and female participation in the labour market is high compared to other regimes. Second, transition policies target activation of youth. Accordingly, the young are expected to be involved in personal development and they possess subjective rights due to their citizenship (Walther, 2009). This is different from Germany and the Netherlands, where the employment-centred regime is dominant (Walther, 2009), and where the concept of youth focuses on adaptation to social positions. This regime is also characterised by a selective school system and standardised training. Transition policies in this regime emphasise prevocational training. Countries representing the liberal regime in Walther's (2009) regime model (the UK and Ireland) and the sub-protective regime (typical of southern European countries such as Italy, Spain and Portugal) are similar in the sense that they both have low standards for training. They also place more emphasis on the family in terms of social security. Culturally, their concept of youth and their expectations of youth's independence differ significantly (Walther, 2009). Under the liberal regime, youth are expected to reach early economic independence, while in sub-protective cultures, youth as an age group do not have such a distinct status. Despite these differences, in all four transition regimes, the shift from education to work has become prolonged, differentiated, less linear and less predictable. However, these developments have taken place to a lesser extent than sometimes assumed (Raffe, 2014).

Along with the formation of the transition regimes, participation in education has become more individualized in many western European countries. As a result of the enhancement of the welfare state and increased provision of education, nonlinear participation patterns have become more common (du Bois-Reymond, 2009; Furlong, 2009). In Finland, the expansion of education has been reflected in the shift in experiences between educational generations. The generations born before 1935 and before World War II lived during a period of scant opportunities, and saw education as an ideal (Antikainen and Kauppila, 2007). For the next generation, born between 1936 and 1955, education was still a means for career progression, in contrast to the following generation. The following generation, known as the welfare generation, born after 1956, has had many educational opportunities. As a result, they view education more as a commodity or something that can be taken for granted (Antikainen and Kauppila, 2007).

At the European level, the increased provision of education has led to discussion about various forms of 'academic drift' in relation to vocational education (Green et al., 1999). First, participation in education, including vocational education, has increased. Second, the role of vocational upper secondary courses with respect to the labour market has changed. It has been proposed that they should be included as an alternative route for upward movement within the formal education system. Accordingly, the contents of vocational routes have been generalised to meet the target of providing the skills and knowledge demanded in successful participation in higher education (Green et al., 1999). Since these trends had already been recognised at the turn of the century, some educational systems have started to emphasise and enhance work-based models of learning as part of IVET, professional tertiary education and higher education (see Räisänen and Räkköläinen, 2014; Tynjälä et al., 2006; Virtanen and Tynjälä, 2008). The workbased model of learning has been implemented as a counter-development to the claimed 'academic drift' in order to increase graduate employability. 
Despite their societal similarities with respect to transition regimes, the Nordic models of IVET have remained different. We will briefly describe these models and the models of Germany and the UK in order to remind readers of the major characteristics of the systems and to provide some background information for the comparisons. These descriptions are mostly based on Refernet country reports, and further details can be found in the individual country reports. More detailed historical accounts of the Nordic models can be found from the Nord-VET project website and project reports (see http://nord-vet.dk/).

\subsection{Finland}

In Finland, compulsory school graduates typically choose either general upper secondary education or IVET after completing their nine-year comprehensive education (Koukku et al., 2012). The expected study time of IVET qualifications is three years (Räisänen and Räkköläinen, 2014). In addition to the school-based IVET, it is possible to complete competence-based qualifications or apprenticeship training. While participation in IVET has increased, as stated above, youth participation in apprenticeship training has been very limited. In 2010 and 2011, the share of those aged 16-19 years participating in apprenticeship training was $0.46 \%$ and $0.49 \%$, respectively, based on information received from Statistics Finland through personal correspondence (Ms. Suvi Vainio, Senior Actuary). Accordingly, competence-based qualifications are chosen mostly by adult learners. In principle, both general upper secondary education and IVET provide eligibility for higher education in traditional science universities and universities of applied sciences. Furthermore, students have the right to combine vocational and general upper secondary studies. This gives them the flexibility to study individually and complete several qualifications concurrently, whereas educational institutions are required to co-operate regionally by legislation (Koukku et al., 2012).

In the early 2000s, the curricula of Finnish IVET were reformed to include an on-the-job training period and skills demonstrations (Koukku et al., 2012; Virtanen and Tynjälä, 2008; Virtanen et al., 2008). These characteristics have counterbalanced the 'academic drift' of school-based IVET in Finland.

\subsection{Denmark}

In Denmark, compulsory school graduates typically choose general upper secondary education or vocational upper secondary education and training, which is taken mainly in a dual system resembling the German dual system (Juul and Jørgensen, 2011; Rolls, 2012). General upper secondary education usually lasts three years and prepares students for higher education. General upper secondary education is provided through four different programmes (upper secondary leaving qualification and higher preparatory/commercial/technical examinations). Two of these programmes are more vocationally oriented and targeted at business schools and technical and engineering courses of higher education, but they do not provide professional competencies. Students attending these programmes need to complete higher education before entering the labour market (Rolls, 2012).

Vocational upper secondary education and training (i.e. EUD in Denmark) is given in twelve vocational clusters that offer a total of 301 vocational qualifications (Rolls, 2012). These qualifications provide access to the labour market for skilled workers, as well as to specific short- and medium-cycle higher education programmes at vocational colleges, academies or university colleges. In addition, a 
recently introduced programme (i.e. eux) bridges the gap between the general and vocational upper secondary education, offering both qualifications for higher education given by the four general upper secondary programmes and access to the labour market (Rolls, 2012).

In $2010,77 \%$ of compulsory school graduates in Denmark continued in further education or training within three months of completing their ninth or tenth grade (Rolls, 2012). The majority continued in general upper secondary education (55\%), whereas one-fifth (21\%) continued in IVET (EUD). Finally, the total number of those participating in EUD (out of a cohort) was almost as high as those participating in general upper secondary education, because the average age of entering EUD is 21. The EUD programmes last from three to four years. In order to enter these programmes, those under 18 are required to have a training agreement with an enterprise or a declaration of their maturity based on an assessment of academic, personal and social competences. They start with one of the 12 foundation courses. Thereafter, students continue in a main programme. These main programmes involve training at the workplace and typically commence with onthe-job placement. Attendance in a main programme demands that students have an apprenticeship contract with an approved training company. If placements are not available, students may participate in another main programme or participate in practical training at the college. Education at EUD is free and students are entitled to an apprentice salary. If they are over 18, they also get a student grant (Rolls, 2012).

\subsection{Norway}

In Norway, general and vocational studies have been provided through a unified upper secondary education structure since 1976 (The Norwegian Directorate, 2012). In 1990, this unified structure was reformed into a ' $2+2$ model' with two years in school followed by two years of apprenticeship training in an enterprise (The Norwegian Directorate, 2012). All compulsory school graduates have the right to attend post-compulsory education and choose from three general study programmes or nine IVET programmes. IVET qualifications typically include two years at school, enhanced by practical training in school workshops and placement in an industry. This two-year period is followed by one year of apprentice training and one year of more independent work. In parallel to this model, there are entirely school-based programmes and programmes following the '1+3 model', with an apprenticeship period lasting three years (Kuczera, Brunello, Field and Hoffman 2008; The Norwegian Directorate, 2012).

Students are expected to find apprenticeship placements individually or with the county authorities' help (The Norwegian Directorate, 2012). In cases of students not finding placement, county authorities have to offer training in school for these students to be able to complete the same final crafts or journeyman examinations. The ' $2+2$ model' qualifications typically allow transfer to post-secondary, non-tertiary education at ISCED Level 4 . Apprentices are entitled to a salary based on collective agreements with respect to the amount of their productive work. In Norway, the apprenticeship training is completed by a trade and journeyman examination, where apprentices demonstrate their skills both practically and theoretically. Some $60 \%$ of vocational students graduate within five years, while the general average on the upper secondary level is $70 \%$ (The Norwegian Directorate, 2012). Participation in vocational programmes has decreased slightly since 2010 (Statistics Norway, 2014). In addition to IVET graduates, who com- 
plete their studies in five years, there are students and apprentices who continue their studies but who are counted as dropouts in the official statistics (The Norwegian Directorate, 2012).

\subsection{Sweden}

In Sweden, an integrated upper secondary education system was established in 1970 and reformed in 1994 to be delivered through a course-based structure (Allen, et al., 2012; Bäckman et al., 2011). Since 1994, vocational and academic programmes have been organised to provide better basic education as well as general eligibility for higher education. After an experimental phase, advanced vocational education, a programme offering tailored education in close cooperation with working life, began in the early 2000s. Accordingly, compulsory school graduates can continue their studies either at vocational programmes or at the higher education preparatory programmes. Among vocational programmes, students may choose to attend school-based education or apprenticeship training. The vocational programmes typically take three years and are organised as modularised programmes. Students of all programmes have the right to study courses that are required for access to higher education (Allen et al., 2012).

Participation in these IVET programmes amounts to one-third of Swedish students who have continued in upper secondary education in the 2011/2012 school year (Allen et al., 2012). In general, participation in vocational programmes has decreased, but there have been differences between programmes. Eligibility for higher education is based on a diploma from the upper secondary school or from municipal adult education (Allen et al., 2012). Since autumn 2013, it has been possible for graduates from vocational programmes to acquire basic eligibility for higher education without choosing an extended curriculum (Olofsson and Persson Thunqvist, 2014).

\subsection{Germany}

In Germany, upper secondary education prepares students for either higher education or access to the labour market (Hensen and Hippach-Schneider, 2012). IVET is offered in three ways: (i) in full time schools, (ii) within the framework of the dual system and (iii) through employment. The dual system has been the dominant form of vocational pathways. Three-quarters of upper secondary students in vocational pathways have enrolled in the dual system (Hoeckl and Schwartz, 2010). There are no entrance requirements in the dual system, but access to vocational schools requires a certificate from secondary general school or a final certificate from intermediate school. Dual IVET programmes take between two and three and a half years, and they are offered in over 340 programmes (Hoeckl and Schwartz, 2010). The command of competencies required for qualification is typically demonstrated in examinations. The Federal Government of Germany is responsible for in-company vocational training and the individual counties (Länder) provide vocational training in schools (Hensen and Hippach-Schneider, 2012). The responsibilities of Länder for the school part of the dual system are reflected in the variance of its organisation and content (Hoeckl and Schwartz, 2010).

In the dual system, trainees attend vocational school for one or two days per week to learn theoretical and practical subjects related to their occupation, as well as general subjects. The practical training provided by a training firm follows 
guidelines which have been set out in the 'ordinances' specific for the qualification in question (Hoeckl and Schwartz, 2010). These ordinances regulate not only the duration of the apprenticeship but also the final exam requirements. Furthermore, they describe the profile of the profession. The competence requirements for incompany trainers demand that trainers be qualified in the training occupation and have command of education theory (Hoeckl and Schwartz, 2010). The training in full-time vocational schools may also include placements. In Germany, participation in IVET has exceeded the European average (27 European Union members' average).

\subsection{The United Kingdom}

In the UK, initial formal vocational education and training is provided by national qualifications frameworks such as the Qualifications and Credit Framework (QCF), National Qualifications Framework (NQF) and Framework for Higher Education Qualifications for England, Wales and Northern Ireland (FHEQ) (Abusland, 2012). The complexity of the English VET system has been criticized recently (Wolf 2011). The entrance requirements for individual qualifications depend on the education providers and examination boards. There are possibilities for transfer of credits between qualifications at the education provider's discretion. Transfer of credits is also dependent on guidelines for recognition of prior learning. Pupil grades from examinations taken for the General Certificate of Secondary Education (GCSE) at age 16 in England, Wales and Northern Ireland are of major importance in determining future education opportunities. In Scotland, the Standard Grades play a similar role as an entrance qualification to IVET (Abusland, 2012).

In England, the period of compulsory education was raised to 17 years in 2013 and will be raised to 18 years by 2015 (Abusland, 2012). Accordingly, local authorities are obliged to find suitable education and training centres for applicants who wish to participate. This guarantee is known in England as the 'September guarantee'. In Scotland, 'Opportunities for All' offers the same guarantee for 16- to 19-year-olds (Abusland, 2012).

Participation in apprenticeships has increased significantly in the UK since 2007/2008 for those 19 and older (Abusland, 2012). Finding apprenticeship locations has been highly competitive in some fields. Recently, courses such as 'Access to Apprenticeship' have improved opportunities to find apprenticeships. This programme was introduced in England in 2011 to support 16- to 25-year-olds not in employment, education or training to gain skills to enter into apprenticeship. In Wales, another programme called the 'Pathways to Apprenticeship' has been designed to give users foundation skills, progress and complete apprenticeship with an employer (Abusland, 2012).

\section{Methods and data}

The aim of this study is to explore whether the increased participation in IVET in Finland can be considered a sign of systemic strength with respect to other IVET systems. By 'systemic strength' we refer to the organization of education as a system that allows fluent access from compulsory education to upper secondary education and further, according to the specificities of laws and decrees defining the national education system and supporting participation in education (i.e. study grants, etc.). We consider progress to higher education and employability as characteristics that could and would indicate if the high rate of participation in 
IVET has coincided with enhancing both individual opportunities and the meeting of societal demands. For that reason, completion of upper secondary and tertiary education and employment would reflect this 'systemic strength'.

In order to observe the progress to higher education and employability, we have used secondary data provided by EACEA P9 Eurydice in its report Key Data on Education. Particular attention will be paid to proportions of the population in the 20-24 age group having completed at least upper secondary education (ISCED 3 ) and having completed the tertiary education qualifications (ISCED 5 and 6; age group 24-64), and the proportion of people in employment by age group and educational level. The secondary data is used without further statistical analysis by comparing the existing data in cross-tabulations and by presenting a figure based on the data.

Our hypothesis is that systemic strengths in the Finnish IVET would be reflected in positive outcomes with respect to completion of upper secondary education and participation in tertiary education. In other words, completion of upper secondary education (ISCED 3) and tertiary education (ISCED 5 and 6) would be more frequent in Finland than in other countries.

The outcomes of education with respect to employment are important and we present a table (Table 4) with information on these outcomes. Since the recession has hit European economies in many different ways since 2008, we think that the general level of employment cannot be trusted as a straightforward signal of the success or failure of IVET in particular fields. The demand for labour force by field has varied significantly as a result of the recession. At the same time, the problems related to using employment as an indicator of the success of education are not limited to periods of recession only. Changes in production and organization of work processes constantly create shifts in skills demands. These changes in turn are heavily dependent on the reorganisation of industrial production and demand globally.

The use of the secondary data results in a number of limitations in our study and the conclusions that we can draw. We discuss these limitations below. Despite these limitations, however, we consider the findings interesting. The attempt to compare countries on the basis of this data reveals challenges for future research and statistical data collection. It is important to recognise these challenges to data collection and analysis when developing evidence-based practice in the field of initial vocational education and training in Europe in the future. In particular, we discuss the limits of the data which we have used in our study:

- Distribution of upper secondary students (ISCED 3) by programme type (general or vocational); years 2000, 2006 and 2009 (Table 1),

- Proportions of population in age group 20-24 having completed at least upper secondary education (ISCED 3) (Table 2),

- Proportions of population having completed the tertiary education qualifications (ISCED 5 and 6; age groups 30-59/64 years, in 2000/2007, and 24-65 years in 2010) (Table 3) and,

- Employment by age group and educational level, \% (Table 4) (adopted from EACEA P9, 2012).

As already noted when presenting Table 1 in the introduction, the information given in Key Data on Education about distribution of upper secondary students by programme type (vocational/general education programme) does not allow for 
comparing differences between ages 16-19 years, 20-24 years and adults over 25 years. As such, it does not help with recognising skill deficiencies and differences between age groups and differences in the fluency of transitions. It hides delayed transition from compulsory education to upper secondary education and does not allow recognition of completion of several former qualifications. The lack of data by educational field and field of production makes it impossible to look at shifts between educational fields.

Second, considering the proportions of population aged 20-24 having completed at least upper secondary education (Table 2), it is valuable that the presented numbers indicate opportunities for education and access to upper secondary education. Unfortunately, they do not differentiate between initial vocational and general upper secondary education or indicate completion by age group. Third, with respect to proportions of population having completed tertiary education qualifications, it was useful to find data that was differentiated by age groups (see Table 3 ). The results considering differences between countries are very interesting. However, in order to compare the opportunities for access to tertiary education provided by the vocational vs. general education routes, there needs to be data on the former education background of those who have completed tertiary education.

Finally, the data on employment is a novelty among Key Data on Education, and this information is provided only in the 2012 report used in our study. This data on employment levels of persons from various educational backgrounds (categorized according to ISCED 0-2, 3-4, 5-6) allows comparison both by the level of education and age groups. While it is good to have data on employment in relation to education, it may unfortunately add to political misunderstanding of the relations between education and employment. Both education and employment are dependent on globalization (Marginson, 1999). It is generally accepted that education enhances individuals' knowledge and skills, and through cooperation with the working world, educational institutions may participate in national innovation systems and the creation of new workplaces. At the same time, the fields of production are dependent on global economic competition and changes in production resulting in changes of employment. Furthermore, the regulation of the number of study sites and provisions on education from various levels affect the supply of a qualified labour force in fields of production. Thus, the route of transition from education to the labour market is influenced not only by the global market economy, but also by the acts of nation states and the accuracy of their educational provision and planning.

In many countries, nation states finance education and control the provision of education and number of study locations available. Furthermore, some states, like Finland, provide educational opportunities as a part of social policy and an alternative to unemployment by increasing the provisions of education during times of recession. Consequently, further information on the completion of multiple qualifications, along with more information on adult education, further education and continuing education opportunities would be welcome to improve opportunities for international comparisons.

In considering the provision of education by national educational systems, it is particularly important to remember that, in many western European countries, the massification of higher education has decreased the relative status of IVET qualifications in the labour market. When there are many higher-education graduates competing for employment with the less educated, the lower status of IVET may be detrimental to vocational graduates. Of course, the outcomes in this 
respect are dependent on how developed the provision of IVET is in the national educational system and how it is culturally appreciated and valued by employers in comparison to higher education. Many countries have also introduced short-cycle higher education to provide shorter higher education routes (Kirsch and Beernaert, 2011). If the data on employment by educational level were more detailed and also considered completion of multiple qualifications and their relation to employment, it would allow recognition of the standing of these two diplomas. The participation in education and completion of qualifications creates opportunities for employment and enhances skills, but it may also be related to underemployment and may hide unemployment. Therefore, it would be helpful to have more information on the number of qualifications completed by people in different age groups.

In the following section, we will discuss the findings from the secondary data provided by Key Data on Education (EACEA P9, 2009; EACEA P9, 2012; Eurydice European Unit and Statistical Office Eurostat, 2002), keeping in mind the shortcomings discussed.

\section{$4 \quad$ Findings}

\subsection{Completion of upper secondary education}

The secondary data provided by the European Commission's Key Data on Education (EACEA P9, 2009; EACEA P9, 2012; Eurydice European Unit and Statistical Office Eurostat, 2002) prompts the research question, 'Are there systemic strengths in the Finnish model of IVET compared to other models of IVET?' from two perspectives: (i) rate of completion of upper secondary education, and (ii) completion of tertiary education. In addition, we discuss employment by educational level considering the observations and limitations expressed above. In this section, we consider the completion of upper secondary education.

The changes from 2000 to 2010 in the number of those having completed at least upper secondary education from ages 20-24 are presented in Table 2.

Table 2: Proportions of population aged 20-24 having completed at least upper secondary education (ISCED 3)

\begin{tabular}{|l|l|l|l|l|l|l|}
\hline Year & $\begin{array}{l}\text { Finland } \\
(\mathrm{FI})\end{array}$ & $\begin{array}{l}\text { Denmark } \\
(\mathrm{DK})\end{array}$ & $\begin{array}{l}\text { Norway } \\
(\mathrm{NO})\end{array}$ & $\begin{array}{l}\text { Sweden } \\
(\mathrm{SE})\end{array}$ & $\begin{array}{l}\text { Germany } \\
(\mathrm{DE})\end{array}$ & $\begin{array}{l}\text { United } \\
\text { Kingdom } \\
(\mathrm{UK})\end{array}$ \\
\hline 2000 & 87.7 & 72.0 & 95.0 & 85.2 & 74.7 & 76.7 \\
2010 & 84.2 & 68.3 & 71.1 & 85.9 & 74.4 & 80.4 \\
\hline
\end{tabular}

Notes. Sweden: Break in series after 2001; Denmark: Break in series after 2003; Germany: Break in series after 2005; Norway: Break in series after 2006. Adopted from EACEA P9, 2012, p. 171.

According to these figures, completion of upper secondary education in Finland has decreased by 3.5 percentage points during this period. Despite this decrease, and along with Sweden, the upper secondary completion rate in Finland is higher than that in the other countries in the comparison. During the same period, completion of upper secondary education has decreased by 3.7 percentage points in Denmark. Regarding Norway, it is important to note that the significant decrease in completion rates is probably an outcome of the changed compilation of statistics, and Norway's numbers are not necessarily comparable. Completion of upper secondary education has remained at almost the same level in Sweden (85-86\%) and Germany (74-75\%), and has increased in the UK from $77 \%$ to $80 \%$. While we 
can conclude from the Finnish perspective that the level of completion has remained at a satisfactory level, because compared to other countries it is relatively high, the decrease in the proportion of completers raises questions.

Is this an outcome of the recession, delayed transition to upper secondary education or dropping out? According to Statistics Finland (2014b), discontinuation of education has decreased by two percentage points in vocational upper secondary education (i.e. IVET) between school years 2002-2003 and 2011-2012 (and also 2010-2011). At the same time, there has been a very small change (less than one percentage point) in the completion of general upper secondary education in Finland. As a result, the level of dropping out in that route is the same as earlier (Statistics Finland, 2014b). Therefore, increased dropping out does not serve as an explanation for the decreased upper secondary completion rate in Finland. Furthermore, the change in the completion is not an expected outcome of change in educational policy. Policy efforts have continuously aimed at increasing participation in upper secondary education, and the development is contradictory to educational policy. It could only reflect an outcome of a highly unsuccessful policy.

In Finland, the educational policy is aimed at increasing participation in upper secondary education by introducing sanctions for those under 20 who do not continue their education (Aho and Vehviläinen, 1997). Since 1996, this group has been unable to receive unemployment benefits if they have not applied for vocational training or participated in labour market policy programmes (Aho and Vehviläinen, 1997). In 2013, this policy was enhanced by the 'social guarantee for young people', which guarantees all students under 25 (and all graduates under 30) employment, internships, education, training, workshops or rehabilitation activities within three months after becoming unemployed (Ministry of Employment and the Economy, 2013).

Despite the policy efforts, the individualised expectations toward education may have amounted to delayed transitions. Very soon after the introduction of the policy, research showed that delayed transitions represented varied aspirations by young people. The dropout youths could be classified as (i) a group clearly opposing schooling and missing future plans; (ii) a group who has a well-defined project for their future and is waiting for the study place that it has targeted; (iii) people who prefer employment and would consider apprenticeships or flexible, individualised forms of education; (iv) those engaged in their hobbies (sports or arts) and who miss individualised opportunities and (v) youth who have vocational aspirations and plans, but who do not want to study whatever is left as a result of 'numerus clausus' and compete for education (Aho and Vehviläinen, 1997). Further research on dropping out from VET showed that dissatisfaction in experiences within their chosen education often resulted in students dropping out, but this was likely to be combined with later participation in another education programme (Komonen, 2001). Accordingly, dropping out was part of a transitional period when youth reconsidered their choices and often took more responsibility for them. Thus, changes in the cultural value of education and emphasis on more individuality and individual choices may have contributed to decreased participation.

Other possible explanations for the decreased participation in upper secondary education in Finland include economic difficulties affecting many families due to recession. In this case, families would have difficulties supporting their children's participation in education despite support in the form of housing subsidises, study grants and free education by the state. Confirmation of the validity of any of these explanations would require further qualitative investigation and interviews of non- 
participators or delayed participators. Regardless, it can be stated that the completion of upper secondary education in Finland and Sweden is on a relatively high level compared to other countries in our study. Both countries have a dominant, school-based model of IVET allowing eligibility for higher education. Still, the participation rate cannot be taken as an indicator of the favourability of IVET in Finland's educational system compared to other countries. More detailed research about transition patterns is needed, paying attention to age groups and prior education levels of those who have completed upper secondary education.

\subsection{Completion of tertiary education}

Completion of tertiary education is most dependent on the eligibility of previous education, field-specific admission criteria and provision of education. Completion of tertiary education by age group in the respective countries is presented in Table 3, considering years 2000, 2007 and 2010 and it is also described in Figure 1 for the years 2000 and 2010 .

The main findings show that participation in tertiary education has increased in all countries, but less so in Germany. While the completion rates in the UK and Nordic countries are more similar in 2010 than in 2000, their difference from Germany has clearly increased. In Finland, the establishment of universities of applied sciences to complement traditional science universities in the 1990s gave a significant boost to massification of higher education (see Ahola, 1997, 2005; Böckerman et al., 2009; Kivinen and Rinne, 1992). This change was followed by the decision that gave all IVET completers formal eligibility to higher education in the late 1990s (Numminen, 2000). Even though the majority of participants in higher education still have general upper secondary education as their former education, this change of eligibility, together with the introduction of universities of applied sciences, removed the stigma of it being a dead end from the IVET route in Finland.

In 2003, 24\% of entrants to universities of applied sciences had initial vocational education as their former education background, whereas $13 \%$ had completed both general upper secondary education and IVET (Virolainen and Valkonen, 2012). Furthermore, there was a small group of students (6\%) who had already completed studies in universities of applied sciences, colleges that preceded these institutions or traditional science universities. In contrast to universities of applied sciences, only $4 \%$ of entrants to traditional science universities had only IVET as their former qualifications, but $19 \%$ had completed both IVET and upper secondary education (Vuorinen-Lampila and Valkonen, 2012). 
Table 3. Proportions of population having completed the tertiary education Qualifications

\begin{tabular}{|l|l|l|l|l|l|l|}
\hline & $\begin{array}{l}\text { Finland } \\
(\text { FIN })\end{array}$ & $\begin{array}{l}\text { Denmark } \\
(\mathrm{DK})\end{array}$ & $\begin{array}{l}\text { Norway } \\
(\mathrm{NO})\end{array}$ & $\begin{array}{l}\text { Sweden } \\
(\mathrm{S})\end{array}$ & $\begin{array}{l}\text { Germany } \\
(\mathrm{D})\end{array}$ & $\begin{array}{l}\text { United } \\
\text { Kingdom } \\
(\text { UK })\end{array}$ \\
\hline 2000 & & & & & & \\
$30-34$ years & 40.7 & 33.1 & 37.7 & 31.8 & 25.7 & 28.8 \\
$35-39$ years & 37.8 & 26.5 & 32.9 & 33.8 & 26.8 & 29.0 \\
$40-44$ years & 36.1 & 28.1 & 32.3 & 28.5 & 26.4 & 29.4 \\
$45-49$ years & 31.4 & 29.6 & 30.9 & 32.9 & 26.2 & 29.8 \\
$50-54$ years & 28.4 & 23.7 & 28.1 & 29.1 & 24.3 & 26.3 \\
$55-59$ years & 27.5 & 18.7 & 24.4 & 24.2 & 22.6 & 21.9 \\
\hline 2007 & & & & & & \\
$30-34$ years & 47.3 & 41.2 & 43.7 & 40.7 & 26.5 & 37.9 \\
$35-39$ years & 43.7 & 35.1 & 39.9 & 32.9 & 26.0 & 32.9 \\
$40-44$ years & 41.9 & 31.5 & 33.7 & 29.0 & 25.4 & 31.9 \\
$45-49$ years & 38.1 & 29.8 & 30.8 & 28.8 & 24.9 & 30.4 \\
$50-54$ years & 33.6 & 29.4 & 32.4 & 28.8 & 25.2 & 30.1 \\
$55-64$ years & 28.2 & 23.5 & 26.6 & 25.7 & 23.1 & 21.3 \\
\hline 2010 & & & & & & \\
$30-34$ years & 45.7 & 47.1 & 47.3 & 45.8 & 29.8 & 43.0 \\
$35-39$ years & 47.7 & 43.2 & 44.6 & 40.6 & 28.3 & 40.4 \\
$40-44$ years & 44.0 & 37.2 & 37.2 & 33.8 & 28.0 & 34.8 \\
$45-49$ years & 41.3 & 28.4 & 35.3 & 30.4 & 26.6 & 33.8 \\
$50-54$ years & 36.6 & 30.6 & 31.7 & 29.5 & 26.5 & 32.2 \\
$55-64$ years & 30.1 & 24.7 & 27.4 & 27.5 & 25.4 & 27.5 \\
\hline
\end{tabular}

Notes. ISCED 5 and 6; age groups 30-59 years in 2000, and 30-64 years in 2007 and 2010. Adopted from EACEA P9, 2009; EACEA P9, 2012; Eurydice European Unit and Statistical Office Eurostat, 2002).

Therefore, it is apparent that increased provision of higher education and the resulting massification of higher education coincide with individuals' raised expectations regarding their future careers. Unfortunately, they may also hide underemployment and career changes obliged by unemployment. It would be helpful to have the information on the former educational background of the various age groups who have completed tertiary education from the targeted countries. In addition, the opportunity to combine these statistics with targeted interviews with various groups of graduates would add understanding to how these countries' higher education strategies have succeeded in meeting individual aspirations, along with meeting changes in production and the demand to produce a highly qualified labour force. Such research would increase understanding about the variety of motivations, as well as dominancy, of why those who complete IVET pursue higher education in different countries. 


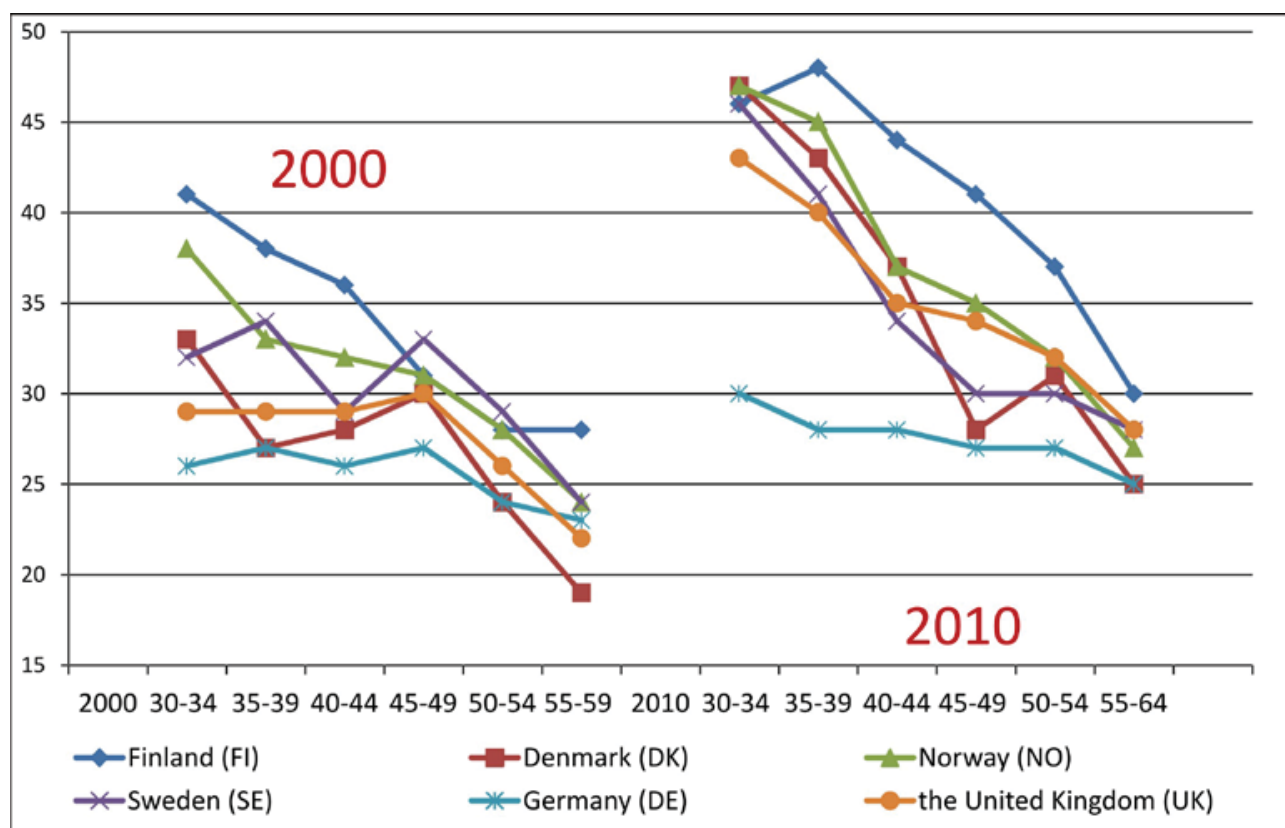

Figure 1: Proportions of population having completed the tertiary education qualifications

Notes. ISCED 5 and 6; age groups 30-59 years in 2000, and 30-64 years in 2010, adopted from EACEA P9, 2009; EACEA P9, 2012; Eurydice European Unit and Statistical Office Eurostat, 2002.

The findings confirm that the eligibility of higher education from IVET has been combined with increased participation in higher education in Finland. Increased participation in higher education has been seen as a means to strengthen the national economy and national innovation systems in times when industrial production has moved to countries providing cheaper production (Schienstock and Hämäläinen, 2001). Accordingly, these findings support our hypothesis that there are systemic strengths in Finnish IVET and they are reflected in participation in higher education. Even though participation rates in tertiary education are high in other Nordic countries, they are even higher in Finland. This highlights that path dependencies within educational routes build up participation patterns in complicated and interrelated ways and that they require more detailed and holistic analysis. For example, it should be asked why Finnish IVET completers have to or want to seek further education in tertiary education. In addition, in the Finnish case, it should not be overlooked that the good learning outcomes from compulsory education that have been presented in Programme for International Student Assessment (i.e. PISA) studies frequently have provided a basis for building more academically oriented IVET (Linnakylä et al., 2011). Based on these grounds, it has been possible to grant eligibility to higher education from Finnish IVET.

Unfortunately, the findings from adult literacy surveys are not quite so flattering to Finnish IVET. According to a recent study by Hämäläinen, Cincinnato, Malin and De Wever (2014), the ability to work and solve problems in technologyrich environments by many Finnish adults who have completed only IVET is at a relatively weak level. One-fifth of them did not manage to meet the lowest expected level. However, it must be remembered that, in Finland, many IVET graduates also complete other education and they are categorised in the study according to their highest educational background (Hämäläinen et al., 2014). 


\subsection{Employment}

As we have mentioned, changes in employment are highly dependent on the economic situation of the countries, and employment in different educational fields depends on the provision of education and development of production in that particular field. Employment with an IVET background is also dependent on the provision of another educated workforce. Still, it is interesting to see how IVET graduates succeed in their working life compared to graduates from other educational sectors. With respect to our hypothesis, successful employment would suggest that there are some systemic strengths in Finnish IVET, even though successful employment is not dependent on the strengths of IVET alone. From the findings presented in Table 4, however, we see that the high rate of completion of IVET does not coincide with a high level of employment in Finland. On the contrary, it seems that all the other countries are doing better than Finland, even though the UK is relatively at the same level. Due to the high completion rates of both IVET and higher education, we can safely presume that Finnish IVET graduates are competing in the labour market with each other and with highereducation graduates, which gives them a less favourable position.

Table 4. Employment by age group and educational level in \%

\begin{tabular}{|l|l|l|l|l|l|l|}
\hline $\begin{array}{l}\text { Education } \\
\text { and } \\
\text { age group }\end{array}$ & $\begin{array}{l}\text { Finland } \\
\text { (FI) }\end{array}$ & $\begin{array}{l}\text { Denmark } \\
\text { (DK) }\end{array}$ & $\begin{array}{l}\text { Norway } \\
\text { (NO) }\end{array}$ & $\begin{array}{l}\text { Sweden } \\
\text { (SE) }\end{array}$ & $\begin{array}{l}\text { Germany } \\
\text { (DE) }\end{array}$ & $\begin{array}{l}\text { United } \\
\text { Kingdom } \\
\text { (UK) }\end{array}$ \\
\hline $\begin{array}{l}\text { Low } \\
\text { (ISCED 0-2) }\end{array}$ & & & & & & \\
25-39 & 60.1 & 67.3 & 65.7 & 62.8 & 56.6 & 57.0 \\
40-64 & 53.7 & 61.3 & 63.0 & 65.9 & 54.7 & 55.6 \\
Medium & & & & & & \\
(ISCED 3-4) & & & & & & \\
25-39 & 78.0 & 83.2 & 84.5 & 84.7 & 80.1 & 78.2 \\
40-64 & 71.8 & 76.9 & 79.8 & 82.5 & 74.5 & 76.0 \\
High & & & & & & \\
(ISCED 5-6) & & & & 87.6 & 88.7 & 88.7 \\
25-39 & 85.0 & 88.3 & 90.8 & 87.6 & 86.1 & 82.3 \\
40-64 & 83.6 & 84.6 & 89.8 & 88.5 & 8.5 \\
\hline
\end{tabular}

Notes. In Finland, the ISCED 4 includes specialist vocational qualifications and further vocational qualifications. Adopted from EACEA P9, 2012.

When considering the employment level of those with only low-level education (ISCED 0-2), we can see that they too are also, and even more so, in a less favourable position in the labour market for all countries, and this effect is exacerbated by age, except in Sweden. Accordingly, it is better to have mediumlevel education and complete IVET than low-level education. At the same time, higher education promotes relatively strong employment, even for the older age groups: their employment is better than that of other educational groups.

The rates of employment were part of the Key Data on Education in this last volume (EACEA P9, 2012). Naturally, it would help to have an opportunity to follow the development of employment every fifth year or so, for example. Additionally, data that allows comparison by fields of production would be very 
valuable. The latter wish may however be undermined by the differences in national typologies and categorisations of fields of production and education.

\section{Conclusions}

The aim of our investigation was to determine whether increased participation in Finnish IVET is reflected in improved outcomes with respect to completion of upper secondary education, completion of tertiary education and employment. We wanted to know if there were some systemic strengths in the Finnish model of organising IVET that would be reflected in these outcomes. In order to investigate our research questions, we used secondary data by Eurydice, Key Data on Education (EACEA P9, 2009; EACEA P9, 2012; Eurydice European Unit and Statistical Office Eurostat, 2002).

Our findings highlight the need for multi-faceted analysis in the systemic position of IVET and its outcomes in terms of completion of upper secondary education, continuation to higher education and employability. Regarding Finland, we know several factors that may have resulted in the increased and comparatively high levels of participation rates in IVET. These include characteristics of Finnish IVET, such as an educational policy obligating youth to participate in education with the threat of losing unemployment benefits; counter-balancing the academic drift by introduction of workplace period and skills demonstrations as part a of IVET; an improved image of IVET as an outcome of skills competitions; changed cultural images of some branches of IVET as an outcome of the vocation's visibility in popular media (e.g. chefs and gardeners); internationalisation of IVET education; and, most importantly, general eligibility for higher education from all upper secondary education (including IVET) and establishment of universities of applied sciences that offer an attractive higher education route for IVET graduates (Stenström and Virolainen, 2014). Still, when comparing the outcomes of Finnish IVET in terms of completion of upper secondary education, tertiary education and employability to outcomes of other Nordic countries, the UK and Germany, we would like to have more data. The present data does not give us confirmation that the increased participation in IVET in Finland has produced better results than the IVET models of other countries in all of these respects. Even though the time span of the study is too short for observing the long-term effects of the latest reforms on the Finnish IVET, the findings emphasise the interdependency of IVET on other educational sectors within the national education system. How are we inclined to argue this?

According to the findings presented above, completion of upper secondary education is at the highest level in Finland and Sweden. In these two countries, IVET has been organised in the educational system so that it is possible in principle for both vocational and upper secondary education students to be eligible for and to proceed to higher education (for those who complete upper secondary education). This characteristic makes their IVET different from the other countries in the comparison. Completion of upper secondary education has also sustained its relatively high level from 2000 to 2010 (Table 2). In sum, since the IVET route is no longer viewed as a dead end, there seems to have been an increased inclusion in education. Conversely, massification of higher education has complicated IVET graduates' transition to the labour market by increasing their competition in the workplace with higher education graduates. While there are claims that tasks in the labour market have been polarised to low skill and high skill as a result of the shift in the forms of production, the change in the skills demands on the labour force 
may be uneven with respect to supply. Still, it is reasonable to presume that the over-supply of highly educated individuals will ultimately compete with the supply of IVET graduates within nation states, except for the highly educated who are willing to move abroad. In all of the Nordic countries included in the comparison, as well as in the UK, completion of tertiary education has increased. In Finland, the massification of higher education has been stronger than in other Nordic countries, which is particularly reflected in the high completion rate of those over 35 years (Figure 1, Table 3). However, the labour market situation for Finnish IVET completers is worse than that in other countries and this is most likely, at least partially, an outcome of the massified higher education (Table 4).

Most importantly, our findings show that in order to have more accurate and confirming data about the outcomes of the systemic characteristics of IVET, we need more detailed statistical data concerning the transitions, in several respects. First, information on the completion of upper secondary education should be related to information about age groups and vocational/general education division of the graduates. Second, considering transitions from upper secondary education to tertiary education from both the vocational and general upper secondary education, information would be needed by age group, former education and the number of qualifications completed (i.e. general/vocational qualification, single qualification, several qualifications). Third, regarding employment, more longitudinal panel groups should be available for comparison, and knowing the number of qualifications completed by those who are employed and unemployed would be helpful. The emphasis placed on the number of individual qualifications completed may sound strange from the perspective of countries where educational provision is scarce. From earlier study results on Finland, we know that completion of several qualifications is surprisingly frequent in both IVET and tertiary education, and this may both reflect and hide difficulties in finding employment (Stenström et al., 2012). Considering the time period of increased success of the Finnish IVET (since 2009, the majority of applicants listed an IVET programme as their primary choice), the statistics presented did not permit a long enough followup period for comparison. Finally, it would be important to also have data that allows comparison of regions within a country. For example, in Germany, the practices of counties (Länder) differ. In Finland, the networks of upper secondary education providers are being restructured, and this may ultimately have an effect on the accessibility of post-compulsory education in counties.

It is difficult to collect satisfactory statistical data that is detailed enough to meet all the demands presented above from all European countries. Still, these European-wide statistics are used for policymaking and it would be valuable to conduct research projects with country groups that could be compared, allowing their developments to be analysed in more detail. Additionally, more information on the development of educational fields would be very welcome, particularly when vocational education is investigated. Unfortunately, the differences in the national statistical categorisations of educational fields may severely hamper this objective. The lack of field-specific comparable data may contribute to the invisibility of IVET to policymakers, while the meaning of numerical data in understanding educational processes has become more and more important (Lawn, 2013). In the case of IVET, it would be crucial to have more detailed data on the transition patterns in order to understand shifts in skills demands and individual, institutional and regional responses to them. The quantitative data analysis should, however, be combined with other research in order to avoid IVET being forcefully 
rewritten by 'powerful others' (Billett, 2014). Collection of qualitative data providing learners' views on the meanings of transitions for learning individuals would be needed. Next, policy analysis would be required to make shifts in transition patterns on the wider, national level understandable. Finally, the voices of teachers and education planners should be heard. Only by hearing their voices will it be possible to adequately compare and develop the quality of vocational education and acquire a more in-depth understanding of the outcomes. 


\section{References}

Abusland, T. (2012). United Kingdom. VET in Europe - Country report. Refernet. Cedefop website: http://libserver.cedefop.europa.eu/vetelib/2012/2012_CR_UK.pdf. Accessed 13 August 2014.

Aho, S., \& Vehviläinen, J. (1997). Keppi ja porkkana. Tutkimus alle 20-vuotiaita aktivoivan työvoimapoliittisen uudistuksen vaikutuksista ja koulutuksen ulkopuolelle jäävistä nuorista [Stick and carrot: a study on the effects of a labour market policy reform that aims to activate the young unemployed a the youth that do not start secondary education]. ESR-publications. Helsinki: Ministry of Labour.

Ahola, S. (1997). 'Different but equal': Student expectations and the Finnish dual higher education policy. European Journal of Education, 32(3), 291-302.

Ahola, S. (2005). Global and local priorities in higher education policies: A headache at the national level? Tertiary Education and Management, 11(1), $37-53$

Allen, M. Färdeman, A., Pontis, C., \& Starbäck, P. (2012). Sweden. VET in Europe - Country report. Refernet. Cedefop website: http://libserver.cede fop.europa.eu/vetelib/2012/2012 CR SE.pdf. Accessed 22 July 2014.

Antikainen, A., \& Kauppila, J. (2007). Educational generations and the futures of adult education: A Nordic experience. In A. Antikainen (Ed.), Transforming a learning society (pp. 217-233). Bern: Peter Lang.

Bäckman, O., Jakobsen, V., Lorentzen, T., Österbacka, E., \& Dahl, E. (2011). Dropping out in Scandinavia. Social exclusion and labour market attachment among upper secondary school drop outs in Denmark, Finland, Norway and Sweden. Institute for Futures Studies Working paper 8. Institutet för Framtidsstudier website: http://www.iffs.se/wp-content/uploads/2011/09/Arbetsrapport-2011-nr8.pdf. Accessed 13 October 2014.

Billett, S. (2014). The standing of vocational education: Sources of its societal esteem and implications for its enactment. Journal of Vocational Education \& Training, 66(1), 1-21.

Böckerman, P., Hämäläinen, U., \& Uusitalo, R. (2009). Labour market effects of the polytechnic education reform: The Finnish experience. Economics of Education Review, 28(6), 672-681.

du Bois-Reymond, M. (2009). Integrated transition policies for European young adults. In I.Schoon, \& R. K. Silbereisen (Eds.), Transitions from school to work. Globalization, individualization and patterns of diversity (pp. 331-351). New York: Cambridge University Press.

Bourdieu, P., \& Passeron, J.-C. (1977). Reproduction in education, society and culture. London: Sage.

Cedefop (2011). Finland: VET in Europe - Country report. ReferNet Finland. Cedefop website: http://libserver.cedefop.europa.eu/vetelib/2011/2011CR_FI.pdf. Accessed 22 July 2014.

Education, Audiovisual and Culture Executive Agency. (EACEA P9). (2009). Key Data on Education in Europe - 2009. Brussels: Eurydice.

Education, Audiovisual and Culture Executive Agency. (EACEA P9). (2012). Key Data on Education in Europe - 2012. Brussels: Eurydice.

Eurydice European Unit, \& Statistical Office Eurostat. (2002). Key Data on Education in Europe - 2002. Luxembourg: Office for official publications of the European Communities. 
Furlong, A. (2009). Revisiting transitional metaphors: Reproducing social inequalities under the conditions of late modernity. Journal of Education and Work, 22(5), 343-353.

Green, A., Wolf, A., \& Leney, T. (1999). Convergence and divergence in European education and training systems. Bedford Way papers, University of London. London: Institute of Education.

Hämäläinen, R., Cincinnato, S., Malin, A., \& De Wever, B. (2014). VET workers' problem-solving skills in technology-rich environments: European approach. International Journal for Research in Vocational Education and Training, $1(1), 57-80$.

Hensen, K. A., \& Hippach-Schneider, U. (2012). Germany, VET in Europe Country report 2012. Refernet. Cedefop website: http://libserver.cedefopeuropa.eu/vetelib/2012/2012 CR DE.pdf. Accessed 22 July 2014.

Hoeckel, K., \& Schwartz, R. (2010). A learning for jobs review of Germany. OECD Reviews of vocational education and training. OECD iLibrary website: http://www.oecd-ilibrary.org/education/oecd-reviews-of-vocationaleducation-and-training-a-learning-for-jobs-review-of-germany-2010_9789264 113800-en. Accessed 12 October 2014.

Jørgensen, C. H. J. (2013). The future of vocational education - learning from the Nordic countries. Roskilde Universitet website: http://rucforsk.ruc.dksite/da/projects/the-future-of-vocational-education--learning-from-the-nordiccountries\%282c4a0833-e354-4fea-a410-3bf7f24af4a3\%29.html. Accessed 23 July 2014.

Juul, I., \& Jørgensen, C. H. (2011). Challenges for the Dual system and the occupational self-governance in Denmark. Journal of Vocational Education and Training, 63(3), 289-303.

Kirsch, M., \& Beernaert, Y. (2011). Short Cycle Higher Education in Europe Level 5: the Missing Link. Brussels: EURASHE. Eurashe website: http://www.eurashe.eu/library/modernising-phe/L5_report_SCHE_in_Europe _summative_report_Jan2011.pdf?197db2. Accessed 20 May 2014.

Kivinen, O., \& Rinne, R. (1992). Educational strategies in Finland in the 1990s. Turku: University of Turku.

Komonen, K. (2001). Koulutusyhteiskunnan marginaalissa? Ammatillisen koulutuksen keskeyttäneiden nuorten yhteiskunnallinen osallisuus [In the margins of educational society? Societal participation of young who have dropped out from vocational education and training.] Publications in social sciences N.o 47. Joensuu: University of Joensuu.

Koukku, A., Kyrö, M., Packalén, P., \& Volmari, K. (2012). Finland. VET in Europe - Country Report 2012. Refernet. Cedefop website: http://libserver. cedefop.europa.eu/vetelib/2012/2012_CR_FI.pdf. Accessed 23 July 2014.

Kuczera, M., Brunello, G., Field, S., \& Hoffman, N. (2008). OECD Reviews of Vocational Education and Training: A Learning for Jobs Review of Norway 2008. OECD iLibrary website: http://www.oecd-ilibrary.org/education/oecdreviews-of-vocational-education-and-training-a-learning-for-jobs-review-ofnorway-2008_9789264113947-en. Accessed 12 October 2014.

Lawn, M. (2013). The internationalization of education data: exhibitions, tests, standards and associations. In M. Lawn (Ed.) The rise of data in education systems (pp. 11-25). Oxford: Symposium Books.

Linnakylä, P., Välijärvi, J., \& Arffman, I. (2011). Finnish basic education: When equity and excellence meet. In K. Branden, P. Avermaet, \& M. Houtte (Eds.), 
Equity and excellence in education. Towards maximal learning opportunities for all students (pp. 190-214). Routledge Research in Education (50). London: Routledge.

Marginson, S. (1999). After globalisation: Emerging politics of education. Journal of Education Policy, 14(1), 19-31.

Ministry of Employment and the Economy. (2013). Social Guarantee for Young People Working Group. Ministry of Employment and the Economy website: http://www.tem.fi/en/current_issues/pending_projects/strategic_programmes and_flagship_projects/social_guarantee_for_young_people_working_group. Accessed 29 September 2014.

Nori, H. (2010). Keille yliopiston portit avautuvat? Tutkimus suomalaisiin yliopistoihin ja eri tieteenaloille valikoitumisesta 2000-luvun alussa [For whom will the university gates open? A study of the selection for admission to Finnish universities and fields of study in the beginning of the $21^{\text {st }}$ century].Turku: University of Turku.

Numminen, U. (2000). Strategies for improving vocational education: The Finnish case. In M.-L. Stenström, \& L. Lasonen (Eds.), Strategies for reforming initial vocational education and training in Europe (pp. 74-91). Jyväskylä, Finland: University of Jyväskylä, Institute for Educational Research.

The Norwegian Directorate for Education and Training with contributions from members of ReferNet Norway. (2012). Norway. VET in Europe - Country Report. Cedefop website: http://libserver.cedefop.europa.eu/vetelib/2012/ 2012 CR NO.pdf.Accessed 24 July 2014.

Olofsson, J., \& Persson Thunqvist, D. P. (2014). The Swedish Model of Vocational Education and Training: Establishment, Recent Changes and Future Challenges. Report 1A from the Swedish project group of the Nord-VET project. Nord-VET website: http://nord-vet.dk/indhold/uploads/Report-1AThe-Swedish-Model-of-VET-final-20141.pdf. Accessed 9 October 2014.

Paterson, L., \& Iannelli, C. (2007). Social class and educational attainment: A comparative study of England, Wales and Scotland. Sociology of Education, $80(2), 330-358$.

Polesel, J. (2010).Vocational education and training (VET) and young people. Education \& Training, 52(5), 415-426.

Raffe, D. (2014). Explaining national differences in education-work transitions. European Societies, 16(2), 175-193.

Räisänen, A., \& Räkköläinen, M. (2014). Assessment of learning outcomes in Finnish vocational education and training. Assessment in Education: Principles, Policy \& Practice, 21(1), 109-124.

Rolls, S. (2012). Denmark. VET in Europe - Country report. ReferNet Denmark. Cedefop website: http://www.cedefop.europa.eu/EN/Information-services/vetin-europe-country-reports.aspx. Accessed 24 July 2014.

Schienstock, G., \& Hämäläinen, T. (2001). Transformation of the Finnish innovation system: A network approach. Helsinki: Sitra.

Statistics Finland. (2008). Ninety-three per cent of completers of 9th grade of comprehensive school and 42 per cent of passers of matriculation examination in 2006 continued studies in the same year. Statistics Finland website: http://www.tilastokeskus.fi/til/khak/2006/khak_2006 2008-01-17 tie 001_en. html. Accessed 23 July 2014.

Statistics Finland. (2012). Direct transition to further studies of completers of the 9th grade of comprehensive school 2005 - 2012. Statistics Finland website: 
http://www.stat.fi/til/khak/2012/khak_2012_2014-01-23_tau_001_en.html. Accessed 23 July 2014.

Statistics Finland. (2014a). Appendix table 3. New students by educational sector and prior education in 2012. Statistics Finland website: http://tilastokeskus.fi/til/khak/2012/02/khak_2012_02_2014-0429 tau_003_en.html. Accessed 22 July 2014.

Statistics Finland. (2014b). Discontinuation of education decreased. Statistics Finland website: http://tilastokeskus.fi/til/kkesk/2012/kkesk_2012_2014-0320 tie 001 en.html. Accessed 19 August 2014.

Statistics Norway. (2014). Upper secondary education 2013. Steady increase of pupils on programmes for general studies. Statistisk sentralbyrå website: http://www.ssb.no/en/utdanning/statistikker/vgu. Accessed 22 July 2014.

Stenström, M.-L., \& Valkonen, S. (2012). Ammatillisen koulutuksen opiskelijoiden opintourat [Student careers in vocational education and training]. In Stenström, M.-L., Virolainen, M., Vuorinen-Lampila, P., \& Valkonen, S. (Eds.), Ammatillisen koulutuksen ja korkeakoulutuksen opintourat (pp. 23-108). Jyväskylä: University of Jyväskylä, Finnish Institute for Educational Research.

Stenström, M.-L., \& Virolainen, M. (2014). The history of Finnish VET. The Finnish country report published by Nord-VET - The future of Vocational Education in the Nordic countries. Nord-VET website: http://nordvet.dk/indhold/uploads/History-of-Finnish-VET-29062014final.pdf. Accessed 8 October 2014.

Stenström, M.-L., Virolainen, M., Vuorinen-Lampila, P., \& Valkonen, S. (2012). Ammatillisen koulutuksen ja korkeakoulutuksen opintourat [Student careers in VET and in higher education]. Jyväskylä, Finland: University of Jyväskylä, Finnish Institute for Educational Research. Reports 45.

Tynjälä, P., Slotte, V., Nieminen, J., Lonka, K., \& Olkinuora, E. (2006). From university to working life: graduates' workplace skills in practice. In P. Tynjälä, J. Välimaa, \& B. Boulton-Lewis (Eds.) Higher education and working life: collaborations, confrontations and challenges (pp. 73-88). Oxford: Elsevier.

Virolainen, M., \& Valkonen, S. (2012). Ammattikorkeakouluopiskelijoiden opintourat [Educational careers of polytechnic students]. In Stenström, M.-L., Virolainen, M., Vuorinen-Lampila, P., \& Valkonen, S. (Eds.). Ammatillisen koulutuksen ja korkeakoulutuksen opintourat (pp. 109-190). Jyväskylä: University of Jyväskylä, Finnish Institute for Educational Research.

Virtanen, A., \& Tynjälä, P. (2008). Students' experiences of workplace learning in Finnish VET. European Journal of Vocational Training, 44(2), 199-213.

Virtanen, A., Tynjälä, P., \& Stenström, M.-L. (2008). Field-specific educational practices as a source for students' vocational identity formation. In S. Billett, C. Harteis, \& A. Eteläpelto (Eds.), Emerging Perspectives of Workplace Learning (pp. 19-34). Rotterdam: Sense.

Vuorinen-Lampila, P., \& Valkonen, S. (2012). Yliopisto-opiskelijoiden koulutusurat [Educational careers of university students]. In Stenström, M.-L., Virolainen, M., Vuorinen-Lampila, P., \& Valkonen, S. (Eds). Ammatillisen koulutuksen ja korkeakoulutuksen opintourat (pp. 191-283). Jyväskylä: University of Jyväskylä, Finnish Institute for Educational Research.

Walther, A. (2009). 'It was not my choice, you know?' Young people's subjective views and decision-making processes in biographical transitions. In I. Schoon, \& R. K. Silbereisen (Eds.) Transitions from school to work. Globalization, 
individualization and patterns of diversity (pp. 121-144). New York: Cambridge University Press.

Wolf, A. (2011). Review of Vocational Education -The Wolf Report. GOV.UK website: https://www.gov.uk/government/uploads/system/uploads/attachment _data/file/180504/DFE-00031-2011.pdf. Accessed 12 October 2014.

Young, M., \& Raffe, D. (1998). The four strategies for promoting parity of esteem. In J. Lasonen, \& M. Young (Eds.), Strategies for achieving parity of esteem in European upper secondary education (pp. 35-46). Jyväskylä: Institute for Educational Research. 